\title{
MY EXPERIENCES IN NAPLES AFTER THE MESSINA DISASTER
}

\author{
BY ALICE FITZGERALD \\ Graduate of Johns Hopkins Hospital
}

Soon after the first news of the awful disaster reached us, I wrote to the president of the Women's Branch of the Red Cross of Florence, to which I belong, and volunteered my services for the Messina and Calabrian sufferers. For some days, meetings were held, messages were received from the minister in Rome saying that we might go if another hospital ship were sent, and, in such inactive way, quite usual in Italian official or semi-official proceedings, several days passed. When notice finally came that no ship would be sent, and as none of the wounded were being sent to Florence, I decided to leave for Naples on my own account.

I asked our president for permission, which was granted, and left for Naples, not knowing if my services would be required or accepted, nor where I should apply, for I soon found that the Red Cross, instead of being one large body of workers with the same interests and aims, is divided into as many branches as there are cities, and there is but little if any connection between them all. For this reason I was not even given an introduction from our branch to that of Naples.

This lack of general unity and co-operation would be a serious drawback in time of war, when the different branches and sections of branches would necessarily have to be placed under one chief.

My journey to Naples was very uneventful, as the hospital trains were not yet coming north, but we took down a number of the men of the police forces, of which the Neapolitan and Sicilian authorities were in great need. During the first few days, one hundred and fifty looters were shot on the spot at Messina, as their regular forces, helped by the Russian and English sailors, were too busy trying to save lives to be able to watch and protect property. When I reached Naples I heard that one of the Red Cross hospitals was established in the new and very fine Excelsior Hotel which had not yet been opened to guests. Its proprietor, with the greatest and most admirable generosity, had offered the use of the fourth floor for a hospital, and from that moment he bore all the expenses of the running of this hospital: food, light, heating, and service were all provided for the patients, doctors, Red Cross officials, orderlies, etc. 


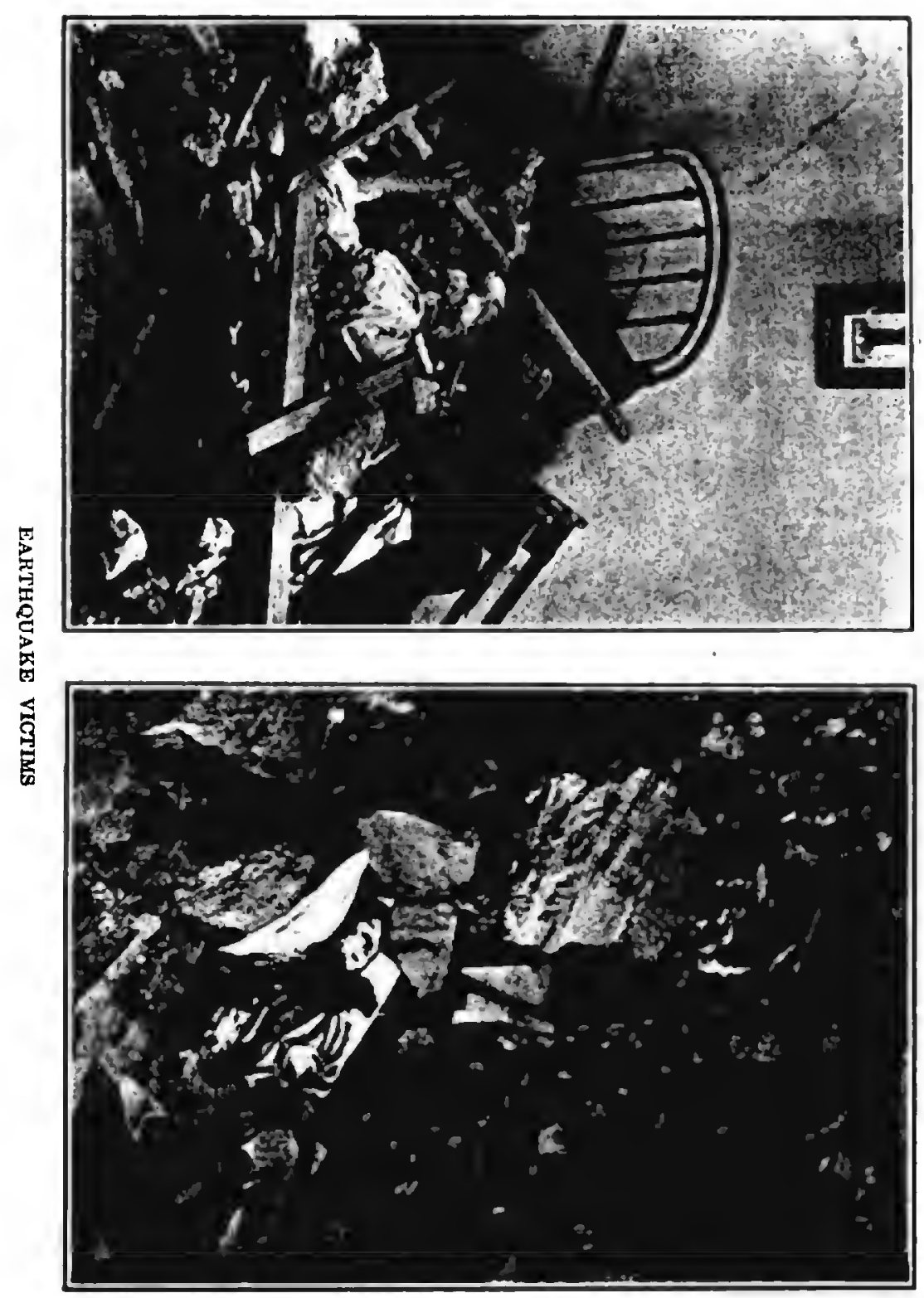

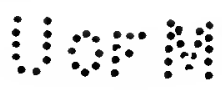




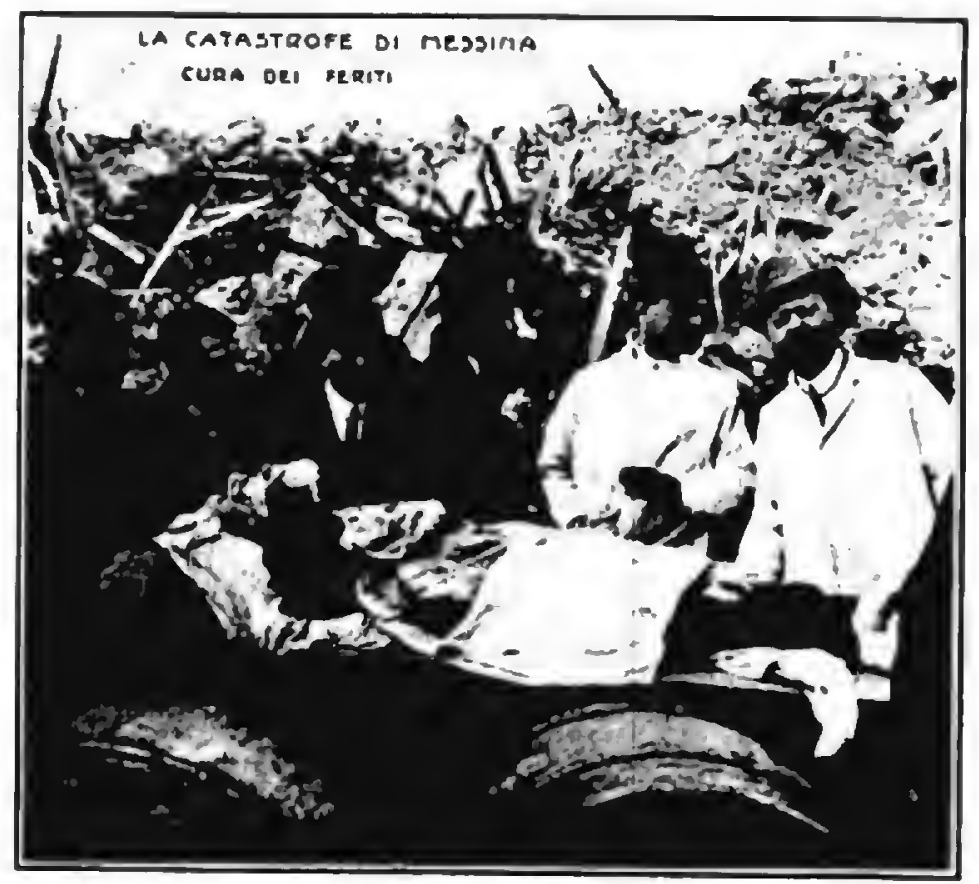

OPEN-AIR SURGICAL DRESSING

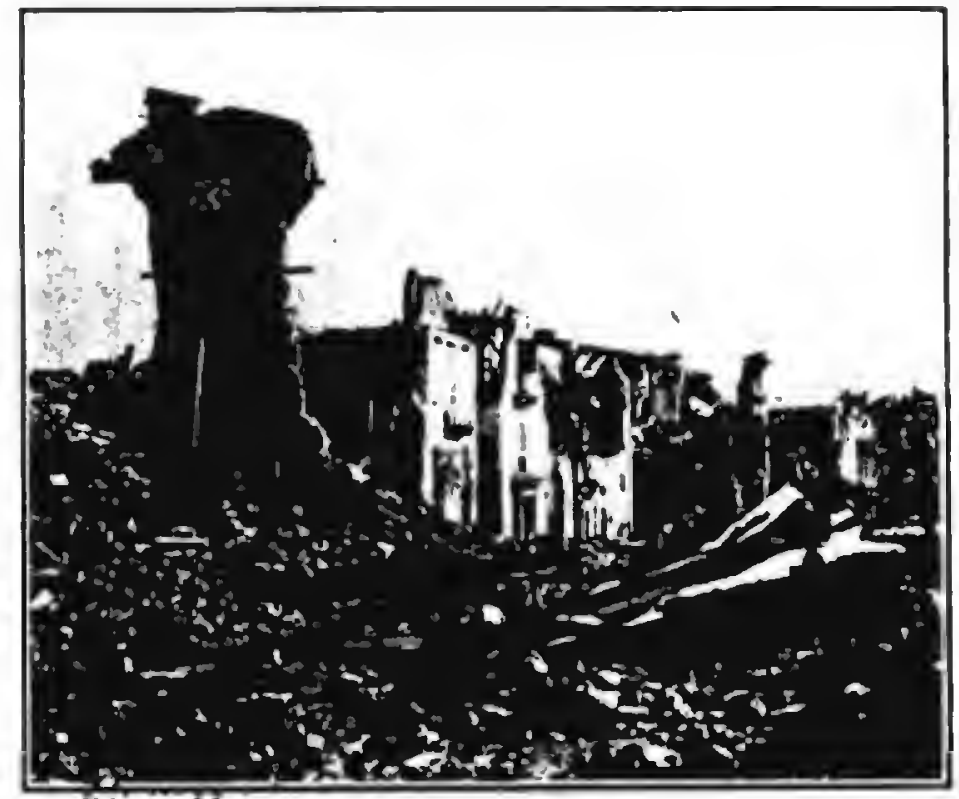

$\because \vdots: .:$

RUINS AT MESSINA 
Such a generous deed cannot be repaid, except perhaps a little in the knowledge that the best managed, the cleanest, and the only hospital where conditions were as near perfect as possible was the one in the Excelsior Hotel. The main. Red Cross hospital, of which this was the overflow, had about two hundred beds.

The evening I reached Naples I went to the Excelsior, as it was very near to the hotel where I was staying, and I intended to make the rounds of all the hospitals to find a place that needed help.

It must be understood that I had nothing to offer as an introduction but my own word to show that I was willing to do anything within my power for the poor sufferers, that I had some training, and, last but not least, that I knew the language.

I said that I had come from Florence for the purpose of nursing, but had not been "officially" sent by the Red Cross. I must add that later on twenty ladies of the Florence Red Cross were officially sent down and given the "blessing and badge," which were the introduction which had not been granted to me, on account of my impatience to get to the scene of trouble. I saw one of the officers of the society who asked me to return the next morning at 11 o'clock, to see the director, which I did, and I was most kindly welcomed and immediately set to work. I found a staff compased of Neapolitan ladies, two of whom were wives of doctors; three Russian women medical students; and three Americans, all women of good common sense, and possessed of the true charity and tact which at all times can accomplish more than training, with no tact and common sense, can ever do.

We also had one lady of the Milanese Red Cross, which had come to Naples with its own doctors, aids, etc., and had started a hospital of its own.

The visiting surgeon was Morisani, a brother of the famous "Senatore Morisani," obstetrician-in-chief to the Queen of Italy. There were a resident surgeon and one or more medical students always on duty to do such work as taking temperatures, giving medicines, etc., which in Italy is not trusted to the nurses.

The patients were mostly fracture cases; all wịth pathetic stories of being caught under the ruins and kept prisoners from two to four days and nights, suffering from their wounds, thirst and hunger, for it was only to those who were partly exposed or within reach that the sailors could bring food and drink twice daily, and leave the hope that the next day they might be rescued!

Among the men patients was a priest, whose arm was badly fractured, but whose future seemed brighter than that of many others as 
the "Church" would always take care of him; and a cart driver, from Reggio, in Calabria, whose work kept him out on the road all night, was on his way home, having reached the main street, when the earthquake took place; his horse was killed and one of his arms was badly broken. He rushed to his own house to find all in ruins and his wife and children dead; the poor man had lost everything!

A little boy, only badly bruised, was considered an orphan until by some lucky accident his mother was discovered lying wounded in some other hospital.

A poor silent, reserved old man had a fractured arm, but rarely spoke, and never complained of his pains or troubles, which must have been even greater than suspected, for he died very suddenly of heart disease. The other cases were more or less a repetition of the suffering and utter despair of men who had lost much or all.

One old man, a church sexton, had dreadful wounds of the scalp, but lingered for days before dying. Another old man, a cobbler by trade, had lost every member of his family, though not badly hurt himself; when cured he had to be sent to the "Albergo dei Poveri," or poorhouse, to finish his sad old days.

Among the women, the cases were perhaps more pitiful, for an Italian woman would hardly know where to turn to earn her own living, if she was not trained for it.

One was the wife of an officer, killed in Messina, with her two children, none badly hurt, but the poor woman's worries were many! She would receive a small pension, but not sufficient to cover her expenses with the two fast growing children. A young woman, a chambermaid, with double fracture of the leg, was under the ruins for seventy-two hours. She had called in vain for help, and owed her life to her brother and father who knew the spot where the house she had lived in stood, and insisted upon digging there. She heard the workers above her, and at last they were able to answer her, but it was a couple of days before they could rescue her. This patient had the worst head of hair it has ever been my fate to comb out. For ten days it had not been touched, some of the ladies.having told her that her hair could not be combed out because of her broken leg! At first I wondered at the excuse, but after a short time I understood the feelings that would prompt such an answer from any " amateur nurse." The hair was still full of mortar, gravel, and clotted blood, and at the back was much like a very tightly woven stuff. I worked for several hours daily as the patient begged not to have it cut, and after many days the remains of the Messina disaster were banished from that hair, at least. 
One old lady who had her foot hurt was a very amusing patient, always fearing she was being neglected in some way, and she had such a convenient little cough ready every time she saw me opening the window and letting in a little much needed fresh air. If she has bronchitis or pneumonia in the next few years, I fear that I will bear the blame for it. However, we became very good friends when she had overcome her suspicions of my methods. She had a bad sore on her back, and as we had no rubber rings I took some cotton and a bandage and started to make her a ring. She watched me carefully, not understanding what my object was, but keeping up a steady stream of protests that she did not need or want the thing I was making! After it was in place, and she felt so much the better for it, she confessed that she had feared that I was going to try and squeeze it around her in some way! 'The same woman took every night a plain lemon cough drop we had brought her and it always made her sleep well!

One very bad case was that of a dressmaker of Reggio who had both feet crushed, and both hips bare of flesh to the bones, and gangrene had set in. At first, amputation of both legs above the knees had been considered but then postponed, and later the gangrene had limited itself to two toes of one foot and one toe of the other. The daily dressing of the hips and feet was most painful, but the patience and will power of the poor Paulina were wonderful, she was so anxious to get well! When I left, she was in a fair condition, but since then she has had one collapse from which she rallied, but it is hard to think that she can recover; she had fever at times and also chills, especially after a particularly painful dressing.

Her diet was quite a surprise to me at first, but I soon learned that every one could have just what and all she wanted, provided we had it on hand. One day when Paulina had more fever than usual, and I thought she would have simpler food, I carefully gave her the broth part of the soup. She looked at me most pathetically and almost reproachfully and said, "That is queer soup with nothing in it," and I had to confess there was cabbage there too, and found she was intended to have it. Once or twice particularly dainty dishes of chicken or sweetbreads were sent to her, but her true peasant nature could not accustom itself to these, and she welcomed back the beloved "maccherone" and " cabbage."

Paulina was a great favorite with all, and the best of all things was always to be had for her. At first she did not like champagne, but very soon asked for it when it was not given to her. Madeira, all kinds of fruit, the best of broth, were among the many donations for her. Her 
only relative was an old aunt, nearly ninety years old, also rescued from the ruins, and she came and "lived with us" though quite unhurt. I fancy that the poor old, simple soul had never seen a set table or a bed with such a never-ending supply of clean linen, for she was the true primitive peasant type.

The other women were fracture cases or simple bruises and were doing well.

The fracture cases were put up in splints and soft dressings, and the leg or arm laid in the wire frames made to fit the part. The treatment consisted of massage around and on the point of the fracture. This was supposed to be done by the doctor, during the first week or ten days, and after that the nurse was trusted to do it; to the massage was added the striking of the part with a wet rag to stimulate growth.

It was very hard to persuade the patients to allow me to change their under sheet as they much preferred being changed into a fresh bed, and this was constantly done.

Bed cradles were very primitive, but practical and easy to make, with a piece of stout cardboard bent into the position of a half circle and held there with a piece of string passed through from one end to the other, like a very tightly drawn bow.

One night I was rubbing the back of a sleepless patient with some cologne (we had much more cologne than alcohol, for it seemed the favorite donation from visitors) and she was much concerned at the novelty of the proceeding, and feared it might weaken her as the doctor had not ordered it. Later, however, she liked it, and frequently spoke of the "miraculous water" I applied which seemed quite a parallel to the "miraculous" cough drop which sent our old lady to sleep so easily.

With the exception of six or eight, the other patients were all the very simple Sicilians or Calabrians of the people, and their dialect was very hard to understand. The meals were always served and sent out to the different patients by the director himself, who was not only a good manager, but one of our hardest co-workers, being always on hand and seeming to grasp every want and necessity before it was generally felt. To him is due the praise for smoothing over all difficulties and making our hospital a "temple of harmony and good will" at all times. This was no easy task, if one considers the variety of nationalities and of conditions of men and women gathered together to do the work.

There were several Neapolitan gentlemen who volunteered some hours, either by day or by night, to help, and they proved ever ready to lend a hand where and when they were wanted. 
The meals consisted of breakfast at 8 M.M.; lunch at $12 \mathrm{M}$.; coffee at 4 P.M. ; and dinner at 6.30 P.M.; all plentiful and nicely prepared. With the lunch and dinner was given the large, full glass of red wine, joy of the Italian heart, and even Paulina took her share.

We had two orderlies on duty who were supposed to work all day and not sleep at night, but, though they may have done the first conscientiously, I know they slept at night just as conscientiously, for we had very little for them to do, and where is the orderly who does not like to sleep at night?

The hours on duty were at first arranged according to every one's desires, the consequence being that too many nurses came in the morning and early afternoon, but no one wanted the late afternoon and evening hours. After a short time, we had the hours arranged by one of the ladies, who, by her experience and charming personality, was the very person to be our "directrice," and things ran very smoothly under her.

I took night duty, but as the custom is in Italy, I was not allowed to take it every night, but only one night in three. With some modifications the schedule would be like this: MIonday, 9 A.M. to 12 M., and 9 P.M. to 9 A.M.; Tuesday, 6 P.M. to 9 P.M.; Wednesday, all day; Thursday, repetition of Monday.

There were usually two of us on night duty, with a medical student, and the doctor and director slept within easy call.

When the patients were well and discharged, the Red Cross Society gave them an entire outfit and change of new clothes, and if they were going to travel each was provided with a warm woollen blanket and money for the journey. As far as the money entrusted to the Red Cross Society of Naples is concerned, I am absolutely sure that the best possible use was made of it, and all immediate wants were attended to.

I think it a pity that the money collected by our Red Cross was not sent directly to the Society in Naples, Palermo, and other branches that were on the spot; there could not be too much money given for the urgent necessities during the first weeks and the outlet to it should have been very free, for I fancy such was the intention of the givers.

During my hours off duty, I visited some of the other hospitals of Naples; of course they were very full and the disorder most apparent. Much of this was greatly increased by the number of untrained people of the Red Cross and other associations, who in all cases were more than willing but were unable to face the situation, through lack of training. 
In every ward where the victims of the disaster were, one saw the ladies of the French and Italian Red Cross, whose uniform with few variations consisted of the long linen coat, an apron with bib over that and a white linen square folded over the hair, something like the Roman peasant head dress. The Red Cross appeared conspicuously on the sleere, apron bib, and head piece. The ladies of the French Red Cross have had both training and experience, having just returned from duty in Morocco, and were much praised for the good work they did.

The Italian Red Cross does not give any regular training, but in some of the cities, like Milan and Florence, they have started a course of lectures and given opportunity for a little practical work.

The lectures in Florence were given by one of the chief surgeons, who very kindly gave his time and that of his assistants, and the free access to his words entirely gratuitously. His lectures were most thorough and interesting, but I would venture to say that they were entirely beyond the object in view, that is, the teaching of a little elementary, urgency, nursing.

A graduate nurse could derive much benefit and pleasure from these lectures, for they went over the ground which we, as a rule, cover in years instead of weeks, and which it is interesting to cover again in after years. The doctor never tired of going over the harder points and trying to clear up difficulties, but it was always from the doctor's point of view and not from the nursing one. Not a scientific term was spared us. One whole lecture was deroted to the names and uses of some familiar and many unfamiliar surgical instruments, sutures, etc., but we were not shown how to make a bed!

The practical work consisted in spending a few hours, for a few mornings, in the wards, watching the doctor make one or two hypodermic injections or a few dressings, and occasionally watching operations. Is it necessary to add that during the operation smelling salts were always at hand, for it was not uncommon to have members of the class faint at the unusual sight of blood, and is it to be wondered at, with no preparatory training whatever?

These hours in the wards should have been filled in with the elements of nursing, but it never entered the doctor's mind that there was anything else to do for the patient, either before or after he had done his part in treating him.

What nursing could be expected after such training? Could any one of those ladies say that she had learned to make a bed, wash and feed a sick or wounded patient, change an under sheet, comb a patient's hair, etc., though she may have learned the name of every bone and 
articulation of the body, and also how to make a surgical knot? If it is to be of any use in time of war or after disasters like the Messina one, the woman's branch of the Italian Red Cross must be organized on the lines of the French, which gives its members training, and the result has been excellent work.

In the hospitals of the "Incurabili," which generally holds eight hundred beds but can take in twelve hundred, and of the "Pace," smaller but also full to its utmost capacity, there was not a quiet spot; patients everywhere, visitors everywhere, and constant talking in every direction. Fresh operation cases had to be placed in these noisy wards, and I have seen, at other times, bodies of the dead patients lying in the crowded wards without a sheet being even drawn over their heads, and was told they might have to wait hours until some one had time to come and get them.

Cases of gangrene were many and some cases of tetanus occurred and were strictly isolated.

The general disorder was naturally more marked even at this time, and the bedside tables were fairly groaning under the gifts of charitalle visitors; one saw shoes, fruit, woollen garments, etc., in hopeless heaps, beside the daily ration of wine, bread and whatever medicines had been ordered.

I saw in one ward, cobwebs which would be the pride of any French wine cellar, and am sure they had not been disturbed for many years, so they conld not, as many other shortcomings were, be blamed on the Messina disaster.

In the "Incurabili" I saw bed screens, small, but still a step in the right direction. I would like to know by what good fortune the screens were placed there, as other Italian hospitals will not hear of them.

The number of cases of amputation was very large. Some small children and women with double amputation at the hips made me wonder if life. were worth the saving for them. Of course many of the maimed will refuse to go into homes or institutions, and will prefer to join the mighty army of beggars, already a serious inconvenience in Italy. I saw two cases of broken backs; one was up in a plaster jacket, but the other one had not been dressed two weeks after the accident. It was remarkable, considering the exposure suffered by them, that so few patients had pneumonia or even colds.

The "Gesu Maria" hospital, which is in charge of Miss Barter, a graduate of the Johns Hopkins Hospital, made by far the best imprea- 
are now scattered, and sending them back to their native land seems the best, for there, at least, they may have a chance of being identified and taken by some relatives who in time might adopt them.

The condition of the poor refugees, as they are sent north to relieve the crowded conditions in the south, is often pitiful, for in some cases they are not sufficiently clad and are almost famished, having been given but one small piece of bread in the twelve hours between Naples and Florence. Does this seem right with all the money that was subscribed and all the clothing which was sent?

Committees of ladies meet the trains as they go through Florence and provide what food and clothing they have on hand. The poor wretches are most homesick, and it is doubtful if they can be made contented and willing to settle down and work in the northern cities. Perhaps later on they can be sent back to their beloved Sicily or Calabria, for they are truly children of the soil and do not bear transplanting.

\section{ANOTHER LETTER FROM NAPLES}

[Our readers will remember that an interesting letter from a Henry Street Settlement nurse, who was in Italy at the time of the earthquake, was given in the editorial department of the February Joursst. The following extracts are from more recent letters by the same writer.-ED.]

Hotel BELlevore, Naples.

You must have another line for I feel you are interested. Order, of a sort, is appearing out of the chaos, and with a few self-imposed rules, so I shall not get tired, I'm going strong.

The improvised operating room is the wonder of the place. A tiny coil of pipe over a gas flame gives a supply of hot water, and a gas stove, one burner, is used to sterilize dressings and instruments-and it's all surgical work! Such dressings! A stream of doctors all day long. 'Tetanus serum has been used in quantities. There isn't a bit of sterilized catgut in the place. . . .

The ladies in the hotel give me clothes every day after dinner, and I go to bed early and take them in a suit case in the morning. I tried to explain who I was. The result is that I am one of the first "nurses settled" in America, and a Signora Inglese of the well-known house of Richmond.

The tragedy, thank God, is lifting a little bit. We are a comic opera lot in our improvised get ups. A woman had wept on my shoulder over the loss of her daughter's betrothed, who had been their sole sup- 